\title{
Reflections
}

\section{Portrait of the Islamic Scholar}

\author{
Ahmed Nezar Kobeisy
}

\begin{abstract}
With the growth in the number of departments, institutions, publications and scholarships relating to Islam and Muslims, concerns are increasing over bias and misrepresentation of the Islamic faith and its subscribers. Muslims tend to attribute this to two factors: American institutions rely mostly on non-Muslims to provide crucial information pertaining to Islam; and most institutions are secular, so it is against their policies and regulations to advocate that any religion holds the absolute truth.

Although these factors pose a real threat to the spread of correct Islamic knowledge, they by no means stand alone. While it is natural for Muslims to object to the idea of non-Muslims teaching Islam because they lack familiarity with it, one is erroneously led to believe that the resolution of the problem is in Muslims taking the task of teaching their religion into their own hands. Two myths must be dispelled: first, that all Muslims are qualified to teach their religion; and second, proficiency in Islamic knowledge sufficiently qualifies a Muslim for the challenging role of accurately transferring this knowledge to those whose perception is so different from his/her own.

This article shows the diversity of the fields of study in which Islam and Muslims may be involved, either directly or indirectly. It then examines the criteria set forth by many educational institutions for determining the qualifications for teaching in these fields. Because higher degrees awarded in pertinent departments in American institutions are not sufficiently educating their recipients in Islamic knowledge, the majority of non-Muslim candidates are unqualified to tackle the issues that involve Islam and Muslims. In an ever-changing world, the qualifications required to teach about Islam and Muslims must not be merely based on Islamic knowledge, but must also encompass a proficiency in global affairs. This immediately disqualifies the typical Muslim scholar. A presenter of Islam must be capable of responding to
\end{abstract}


the challenges of the time, place, and people, without violating the policies and secular nature of the institution and without distorting or altering the religion.

Since a real lasting solution is not presently in sight, some Islamic communities, in an attempt to put an end to bias and misrepresentation, have come up with quick fixes. This article describes how Muslim communities in Youngstown, Ohio, and Syracuse, New York, have become involved in educating their non-Muslim neighbors by responsibly cooperating with various local academic institutions. The author hopes that this study will prove helpful to other communities of Muslims and non-Muslims in their attempt to reach out to each other.

Numerous and serious are the challenges Islam must face and overcome in the United States, particularly in higher education institutions. In our very complicated and scientifically sophisticated time, the validity and applicability of Islam is being challenged in all aspects of life. Until now, Muslims have met the challenge by employing methods limited to either living through the heritage of Islam's past generations, from the dawn of Islam to the renaissance in Europe, or by secularizing and Westernizing their Islam so that it consists only of personal convictions and ritual practices that are performed in the houses of worship, thus isolating it from all other aspects of life.

Although we have failed to establish or demonstrate successful Islamic institutions at work, speeches and conferences are being organized around the globe with exciting titles, intimidating at times, all revolving around the tirelessly repeated slogan "Islam is the solution." While this is a fact, it must be practically demonstrated for our argument to be convincing. For instance, we brag about the justice of 'Umar ibn al-Khattāb and the scientific achievements of Avecenna, Al-Bayrūni, Jaber ibn Hayyan, and many others while, at the same time, we fail to follow their examples. Although we Muslims adamantly oppose the secularization of Islam, we have succeeded in keeping the authority of Islam marginal in Islamic countries, as well as in non-Islamic ones. The accolades in social justice, administrative and educational institutions, and scientific discoveries belong only to those who have the creativity and courage to lead the way and not to those who stand still, let alone those who live as hostages to the culture and traditions of the past. The Qur'an clearly says: "They are people that have passed away, they shall reap the fruits of what they did, and you shall for what you do" (2:134). ${ }^{1}$ 
Two areas in higher educational institutions that require improvements concerning Islam can be described as more effective and easily accessible than others, namely, teaching and textbooks. Of the two areas, teaching is the more important and essential factor that influences the selection of textbooks, the development of syllabi, and the direction and subjects of research. It can also be influential in developing public policies and in forming public opinions through several media.

In this paper, I will discuss current trends in higher education in relation to Islamic scholarship and suggest criteria for qualifications of what constitutes an "Islamic scholar." I will also discuss the role communities play in developing a positive attitude and in promoting adequate representation of Islam through proper education.

\section{Demand for Islamic Scholars}

With the phenomenal growth in departments related to Islam, Islamic civilizations, and Muslims, the demand for Islamic scholars is growing although not in proportion to the real need for them. In the same week two issues of The Chronicle of Higher Education and Religion, at least four ads were run for Islamic scholars for teaching positions. While this may not be representative of the size of the demand, it represents, no doubt, a new trend. In addition, discussion about Islam and Muslims have been commonplace in departments, and courses found in the departments of women studies, global affairs, cross cultural studies, Near Eastern studies, history, political science, anthropology, sociology, medieval studies, religion, family studies, and even in schools of medicine! ${ }^{2}$

Reasons for such growth are not well documented. We can, however, safely exclude the genuine desire to educate about Islam and its subjects. Nasr (1987) states: "The extensive interest in Islam displayed in recent years in many Western circles, far from helping to make the various aspects of Islam better known, has often caused confusion."

Although these studies and departments do not reflect, in most cases, a genuine interest in Islam or Muslims, they should have elicited an adequate response from the Muslim world. Instead of providing an ever-growing market with an adequate number of highly qualified scholars, we watched passively as Jews, Christians, and even Hindus with an education in anything but Islam were granted positions, thus leading to increased misunderstandings and negative stereotypes of Islam. To be fair, I have to say that a few Muslims, through personal effort, have managed to occupy some of 
these positions, although many of them still lack the qualifications, the vision, or the strength to stand up for change. Therefore, nothing significant has been achieved.

Because this is a large topic I will limit myself to discussion of a few areas only.

\section{Language}

Understanding language is very important in communicating a message clearly and effectively. In an attempt to eliminate widespread misrepresentation, Ted Kopple recommended that "Muslims provide more spokespersons who are 'succinct and pithy,' who know enough 'colloquial English' to make articulate and intelligent statements in public delivery." ${ }^{3}$ Islamically speaking, knowing language is a condition for knowing and applying the Shari'ah. For example, scholars of both 'Usul al-Fiqh and Hadith have made it a condition for the mujtahid to know the Arabic language in its classic form and also to know its Qur'anic and prophetic usage.

In 'Usul al-Fiqh, Imam al-Shatibi stipulates the qualifications of ijtihad in the Shari'ah by saying: "He/she must be an Arabic speaking person who understands the Arabic language similar to that of al-Khalil, Sibawayhi, alKasa'i, al-Farra', or those who are in their rank or close to that."4 As alShatibi puts it, lacking a good command of the language "leads the person to depend on the understanding of others, which deprives him/her of the ability to making ijtihad and thus remains as a muqallid (i.e., a follower of others)."5

In the science of Hadith, it is not acceptable to narrate the meaning of the Hadith unless the person "is well versed in the Arabic language, knowledgeable and certain of its vocabulary and their different meanings depending on the context." 6

This is in the understanding of Islam. Communicating it is no different. Understanding the language in the contexts of both the culture and the literature is very essential. In the "Book of Knowledge" of Sahih al-Bukhari, there are many chapters and narratives that encourage and provide guidelines for selectivity in preaching Islam - selectivity of the preaching time, types of information, and usage of the language depending on the mental and intellectual readiness of the audience. ${ }^{7}$ Ali ibn Abi Talib was reported to have said: "Talk to people according to their mental caliber lest they may convey wrong things about Allah and His Messenger."8

Al Qarafi states what translates to the following: 
Applying rulings as we have always known them to a set of traditions or customs that have undergone change constitutes a departure from ijma' and reflects an ignorance of religion. Rulings in every aspect of the Sharitah (Jurisprudence) dealing with custom and tradition change with the change in customs to accommodate the new customs. This flexibility is not considered as renovation (i.e., tajdid: reconsideration or initiation) in the ijtihad of followers and imitators and, therefore, the prerequisites guiding the necessity for ijtihad do not apply here. This is not but a rule decided on and confirmed by scholars through ijtihad. ${ }^{9}$

\section{Ibn Qayyim also states:}

It is not befitting a mufti (jurist) to pass judgment or ruling in matters of iqrār (i.e., acknowledgment or admission), oaths, wills, and others pertaining to semantics, using for his frame of reference his own understanding of words when he lacks background knowledge of the common usage of these words as agreed upon by a particular group of people. Instead, he ought to consider in the judgment for that group of people, the interpretation in accordance with their understanding and usage, otherwise, he stands to stray and lead others astray. ${ }^{10}$

A scholar must understand that Western intellectuals consider religions to be only symbol systems of worldviews. In such an environment, a claim to the absolute truth that is based only on emotions is far more harmful than otherwise. Wiggins states: "Such claims can not make compelling sense to many critically thoughtful [people] in today's world for the reason that 'the universe maintains its inscrutable ambiguity." "11 In a culturally and religiously diverse society, people need to be introduced logically and intellectually to the facts, which they can then judge by themselves.

In addition, the scholar may be faced with mistakes that need to be challenged, confronted, and corrected. Christianity and Judaism are often called "Western religions" in cultural and religious literature, which is not true either historically or otherwise. Many translators of the Qur'an (e.g., Ali, Asad, Maududi, or Irving) use the term "niggardly," which is offensive to most African Americans. A substitute could easily have been found. ${ }^{12}$

\section{Education}

In approaching this issue, I would like, for the sake of convenience, to divide education into two types: religious and nonreligious.

As for religious education, the Islamic heritage is extremely rich in all fields of Islamic sciences (e.g., sciences of Qur'an, Hadith, 'Usūl al-Fiqh, 
Fiqh). Our duty as Muslims is to draw upon our heritage in dealing with new issues rather than staying confined to the same old ones. Unfortunately, most Islamic educational institutions are designed to teach only the memorization and repetition of narratives, old verdicts, and fatāwa, regardless of the time and place that influenced them. While Muslims agree in theory that the doors of ijtihad are open, we have in practice closed them and kept ourselves hostages to what was only intended for specific circumstances and particular conditions.

Dr. al-Qari wrote:

Do I anger any one if I claim that we - seekers of knowledge - are about to be only reciters and narrators? Reciters of the Qur'an, reciters of Hadith, reciters of fiqh, or readers of history. We are readers and reciters of books and narrators of books. The mentality of narrators is widespread and dominant among us, whether some of us have felt it or not. Even those who study (or teach figh) are narrators! And, therefore, studies in the sciences of narrations have blossomed among us and the studies of manuscripts have also blossomed. The orientation of most of the fiqh seekers in universities and studies and research centers is toward narratives and the commentaries on manuscripts. Where is fiqh, where is the expertise? Where is the ability to understand, critique, and analyze? The sciences of Qur'an, Hadith, and Arabic language are all but means to one product, fiqh. Fiqh (i.e., understanding) of the noble Qur'an and the prophetic tradition are the products. The figh of history and the solution of contemporary problems are formed according to the Shariah.

At this time, when ideological war (braining washing) is being waged against us, in this very difficult time, are we all to be only narrators and reciters of manuscripts - experts in museums and libraries? Most fiqh seekers occupy themselves with the sciences of narration, commenting on manuscripts - digging graves for them. Is the reason for this because dealing with the past is easier than dealing with the problems of those who are living? ${ }^{13}$

The problem lies in our educational systems, which train graduates to live in the past and totally ignore the present, let alone the future. This is not the only problem. Dr. Al-Qari outlines two more dilemmas facing our education systems:

- The separation between areas of Islamic knowledge, to the extent that a Ph.D. graduate in Hadith may not know anything 
about the Qur'an and its sciences, while a graduate may know neither the Qur'an nor Hadith.

- The continuously declining standards in our education systems, so much so that a Ph.D. graduate in any field is not even qualified in his own particular field. ${ }^{14}$

According to this analysis, most of our Islamic scholars in the West are not qualified to respond to the issues in a world that is changing as fast as the speed of light. At best, the response will come too little, too late.

By nonreligious education, I do not mean secular education; rather, I mean the study of disciplines that are not derived directly from religious sources, but which are very attached to religion through the humanities. Previously, I indicated that issues relating to Islam are discussed in courses dealing with anthropology, economy, political science, history, education, international relations, geography, psychology, and even the physical sciences including medicine. An Islamic scholar must therefore be aware of the trends and foundations of these fields and know about important social theories such as alienation, class struggle, and class consciousness of Marx, reason and power of Nietzsche, and knowledge and power of Foucault, to mention only a few. Such knowledge has become a necessity in any intellectual discourse, and without it the Islamic scholar has no ground from which to engage in discourse. An understanding of symbolic interaction, phenomenological theory, feminism, and postmodernism can help Muslims in their struggle for justice and equal rights with the mainstream population. They can also help in directing the research toward more sophisticated theories and applications. Knowledge of psychological theories such as Freud's infantile sexuality and Oedipus complex and theories about human nature and human development are necessary for the development of their Islamic counterparts.

Darwin's theory of evolution has changed the way people look at themselves and others. Despite the heavy criticism and wide condemnation this theory has received from both scientists and religious communities, it remains dominant in sociological and scientific fields. Yet, there are Islamic scholars who know nothing more than its name and the name of its founder, or worse, who have never heard of it. How can we prove the universal validity of Islam if Muslims until now have not unified their opinion on scientific controversies such as cloning? Unfortunately, there are voices in the Muslim world that condemn science, prosecute scientists, and deny 
scientific facts that were established more than thirty years ago. For example, while claiming Islamic authority, al-Muqhim wrote a series of articles in Al-Dawah magazine denying that Armstrong and his crew walked on the surface of the moon in July $1969 .^{15}$ The debate continued for several weeks falsely portraying Islam in conflict with science, something that Europe faced in the Dark Ages. I am not calling for a ruling that approves or disapproves; rather, I wish that Muslims would stop criticizing and instead provide Islamic alternatives to faulty scientific thinking, immoral lifestyles, unbalanced ideologies, unproven theories, and ineffective approaches to problems.

An Islamic scholar at any institution must expect to be called upon by the media and other agencies to comment on religious, political, social, and economic events; provide clarifications; and act as a spokesperson for Islam. The scholar must be an activist in promoting Islam and the rights of Muslims without violating the secular nature of institutions. To accomplish this, he/she must be at least familiar with that nature.

The subject of fiqh is defined as "the acts of Islamically responsible individuals (mukallafin) and issues that face them are examined to determine the Islamic ruling on them as lawful, prohibited, mandatory, recommended or disliked." ${ }^{16}$ Discussing issues and norms and justifying or debating them in relation to the revelation all constitute aspects of figh. ${ }^{17}$

It amazes me that in the seventh century, Imam al-Ghazali talked about worldly knowledge ('ulüm dunyawiyyah) as a collective obligation (fard kifayah), a fact that has been ignored by many Muslims since his time, thus leading to a rapid decay in the various fields of knowledge and to the dependence of the Ummah on its historic enemy and rival, the West. In summary, Muslims have failed in acquiring a useful education, one that combines the religious and worldly domains.

\section{Research}

One positive aspect of postmodernism is that it legitimizes and empowers minorities and the new voices of a diverse and multicultural society. Foucault argues that knowledge and power are inextricably linked. He concludes that human sciences have become instruments of power by shaping the views and behaviors of human subjects. ${ }^{18}$

Research in fields such as anthropology, psychology, history, economics, and sociology, must be conducted in the field with real people, not in 
libraries. If performed objectively and in an organized manner, research can and should be employed to serve the following objectives:

1. Advance the process of Islamization of knowledge in both quantity and quality.

2. Liberate Islamic thinking so that it is free to move beyond rhetoric and theory to application and practice supported by research and investigation.

3. Demonstrate the validity and applicability of Islam in aspects of life that have long been thought of as only secular.

4. Help shape and improve the image and views of Muslims of themselves and of others.

5. Help shape and correct the views of non-Muslims on Islam and Muslims.

6. Participate in the formation of society through knowledge and scientific research.

\section{Identity}

Like other minority groups, Muslims in the United States have the advantage of being "unhyphenated" Americans. If barriers such as ethnicity and nationalism are abolished, Muslims can benefit. Muslims speak of themselves as one community without the barriers of race, language, or nationality. When practiced, Islam fosters unity and, consequently, collaboration and productivity. It also helps them determine the way they see themselves in the matrix of the United States. Muslims must think and act as Americans and concern themselves with American issues. ${ }^{19}$ This requires detachment from un-Islamic practices in Islamic countries without either abandoning their affiliation to the Ummah or forsaking their support of Islamic affairs wherever they may exist. The Islamic scholar's identity as an American will positively affect on the effectiveness of his/her contributions to various academic fields. We have been hurt by continued, intentional, and deliberate portrayal as foreigners and nonresidents. 


\section{Campus and Community Involvement}

Humanism is growing rapidly and gaining influence in both public and private life. The Islamic scholar must, therefore, champion humanitarian causes and social services on campuses and in the surrounding community. Justice, mercy, and concern for society at large, which are Islamic principles, can best be demonstrated through involvement in projects designed to improve the lives of all members of the community such as fighting violence and volunteering to serve the elderly, the homeless, and the disabled. High visibility will also bring recognition of Islam as an Abrahamic faith and will also help in the inclusion of Muslims in future discussions, planning, and policies.

These qualifications are not meant to substitute for those stipulated for a mujtahid in the texts of 'Usūl al-Fiqh, but rather to complement them given the new challenges of our time and place.

The dominant thinking and behavior in higher education institutions presents a paradox that we must end. While Muslims feel that most Muslims, especially graduates of Shari'ah, can teach Islam to non-Muslims at any level including the university level, higher educational institutions require, in addition to a degree in religion, a number of publications on Islam covering critical thinking of the Qur'an, the prophetic tradition, and Islamic history. Sometimes anti-Arab and anti-Islam attitudes are considered more attractive. While the guidelines ruling the secular nature of institutions are considered a factor in fostering a misrepresentation of Islam, they do not call for it. The true culprits are the administrators who interpret and enforce these guidelines according to their whims, for they are the ones who intend to mislead their clients and the public by institutionalizing such misinformation and misrepresentation.

\section{Models to Improve the Image of Islam}

In an attempt to take charge of the situation and to play an important role in improving the image of Islam in higher education institutions, the Islamic communities in both Youngstown, Ohio, and Syracuse, New York, have made remarkable achievements and gone through unique experiences that are worth looking into and learning from.

The Experience of Youngstown

In March 1996, the Message, the Minaret, Impact International and the Economist published the following ad: 


\section{University Professor of Islamic Studies}

Youngstown State University invites nominations and applications for a newly endowed position in the Department of Philosophy \& Religious Studies which carries the title "University Professor of Islamic Studies." This is a full-time, tenure-track position. Qualifications for the position include an earned doctorate in philosophy or religious studies, extensive knowledge of the theory and practice of Islam, formal education in Islamic theology, fluency in speaking and writing both English and Arabic, and knowledge of the major religions of the world. Review of applications will begin on March 1, 1996, and will continue until a suitable candidate is found. Rank and salary are open. The effective date of the appointment is September 15, 1996. Applications should include a letter of interest, a current resumé, official copies of transcripts, and the names, addresses, and telephone numbers of three references. Interested parties are encouraged to request a full description of the qualifications and the duties of the position. Such requests, as well as nominations and applications, should be directed to the Department of Philosophy and Religion.

YSU is an affirmative action/equal opportunity employer. ${ }^{20}$

Requesting formal studies in Islamic theology is an unusual practice in recruiting Islamic scholars for teaching Islam. This formal training was required because the Islamic community in Youngstown had reached an agreement with the University to establish the position to promote the understanding of Islam. The Muslim community agreed to contribute an endowment of $\$ 500,000$ over five years to cover the expenses of the position; and when contributions reach one million dollars, the position will become chair of a department with a private office, appropriate secretarial support, research assistant, and an operating budget of $\$ 10,000$ a year.

The Islamic community's intent for this project and the scholar's qualifications are stated in the following agreement:

\section{Sponsor's Intent}

The Sponsor intends that its contribution of funds to the University will facilitate the following goals:

1. Assure the permanency of a competent scholar in Islamic Studies on the faculty of the University;

2. Assure that Islam remains a topic covered in the curriculum of the University;

3. Promote the academic understanding of Islam;

4. Assure the identification and communication of the doctrinal and ethical themes of Islam as integral aspects of the teaching of world religions and nonreligious world views; and 
5. Encourage discipline-related public service by a University faculty member who is a scholar of Islam and encourage the inclusion of the Islamic Society of Greater Youngstown in discipline-related public service by such a scholar.

In order to best effectuate the Sponsor's intent, the University will seek the most qualified individual available for the position. The University will conduct a search for an individual who possesses all of the qualifications the University considers appropriate for a faculty member at YSU and at least the first nine qualifications listed below. The balance of the qualifications listed below shall be considered by the University in its search as highly desirable, but not required.

1. Earned doctorate in philosophy or religious studies;

2. Extensive knowledge of the theory and practice of Islam;

3. Outstanding verbal and written communication skills;

4. Formal education in Islamic theology;

5. Fluency in speaking and writing English and Arabic;

6. Record of effective teaching;

7. Ability and readiness to engage in discipline-related public service;

8. Ability and readiness to serve as an interpreter of Islam;

9. Ability and readiness to accept normal faculty duties at the University in teaching, scholarship, and University service;

10. Ability to teach a variety of courses offered by the Department of Philosophy and Religious Studies at the University;

11. Knowledge of the major religions of the world;

12. Ability to identify and communicate the doctrinal and ethical themes of Islam;

13. Record of scholarship on Islam and other world religions;

14. Active research agenda; and

15. Demonstrated commitment to the goals of a modern metropolitan public university. ${ }^{21}$

From the above listed qualifications of the scholar, the cause of Islam can be furthered and promoted remarkably in a way that benefits both Muslims and non-Muslims.

While the success of this work cannot be evaluated immediately, we can say with confidence that it is a step in the right direction and a model that should be followed.

Though some communities may not have the ability to collect the necessary funds for such a project, cooperation between the local Islamic communities and the colleges and universities can be very productive and rewarding. In Syracuse, New York, for instance, through cooperation with the Syracuse University (while negotiations are in progress for the estab- 
lishment of a chair for Islamic Studies), the Islamic Society has succeeded in the following:

1. Recognition of İd al-Fitr as a University holiday.

2. Serving Muslims with halal food under the supervision of the Islamic community.

3. Establishing the authority on Islamic studies and affairs for the Muslim community. This resulted in several positive achievements:

- deciding the readings on Islam in a course involving Islam.

- making visitations to the mosque as one of the requirements of the course for all students and staff. Currently more than 130 students visit the mosque together every semester from only one course.

- designating Islamic speakers to different classes.

- acting as the sole interpreter of Islam and spokesperson on issues related to Islam.

We hope that the chair project will soon become a reality.

\section{Conclusion}

Penn State University at University Park circulated an ad at the end of 1996 recruiting an Islamic scholar to teach in the history and religion departments. The position did not require a formal education in Islam; on the contrary, it required the person to be critical of Islam's holy texts and its history. While Islam does not fear critical thinking, knowledge of the meanings, intents, and contexts of the revelation is required before forming an opinion on it. Although Islam itself forbids making statements on behalf of religion without 'ilm (knowledge), it invites people to examine it, reflect on it, and even challenge it. Opening the door to the unqualified to offer their interpretation of the revelation not only institutionalizes the misunderstanding of Islam among non-Muslims, it damages Muslims' faith in Islam as well. Muslim students join colleges at a relatively young age with little if any understanding of Islam. Courses related to the study of Islam appeal to them as electives. In such courses they get intensively bombarded with negative things about Islam against which they have no defense. Their faith in Islam, at best, changes into doubt and may infect family and friends. The influence of these departments and scholarships is far more damaging than is believed. The establishment of well-intended scholarships on Islam is, therefore, necessary and constitutes an Islamic obligation to counter ongoing misrepresentation. 
Some wealthy governments and individuals have contributed generously to various universities and colleges for various reasons, the validity of which is beyond this article to judge. The effectiveness of such contributions, however, has proven helpful to neither Islam nor Muslims. I call upon the Islamic communities to become more involved in deciding who should represent Islam and how.

The solution to the problem of misinformation and misrepresentation is manifold. First, Muslims need to redefine the qualifications of Islamic scholars and reform their Islamic educational institutions in order to face the new challenges ahead. Islamic curricula must incorporate knowledge of society, science, and environment to the already existing course work of fiqh, Shari'ah, and Arabic language. This may warrant the establishment of Islamic theological seminaries in the United States.

Second, we need to improve the financial and social status of Islamic workers to equip them with the means necessary to be effective. This will also encourage those Muslim youths demonstrating aptitude and scholarship to consider work in the Islamic field as a career. Last but not least, we need to exert political and financial pressure at the municipal, state, and national levels to promote the view that attacks on or misrepresentations of Islam are politically incorrect. This will provide at least a fair if not a favorable treatment of Islam.

\section{Notes}

1. M. Malik, English Translation of the Meaning of al-Qur'an (Texas, 1997), 128.

2. A. Kobeisy, "Women in Islam; Myths or Facts in American Universities," presented at the fourth annual Symposium of the International Institute for Arabic Studies in America (IIASA) (1996).

3. The Minaret Magazine (August 1997): 20; and see also the Newsletter of American Muslim Council (August 1997).

4. E. al-Shatibi, Al-I'tisäm (in Arabic) (Egypt: Dar Umar Ibn Al Khattab, no date), $297 / 2$.

5. Ibid., 298/2.

6. J. al-Suyūti, Tadrīb al-rawy fi sharh taqrïb al-nawawi (in Arabic) (Egypt: Dar AtTurath, 1972); and M. al-Tahhan, Tafsir mustalah al-hadith (Beirut, Lebanon: Dar alQur'an al Karim, 1979).

7. Sahih al-Bukhari, Vol. 1 (Beirut: Dar al-Arabia, 1985), 50-99. See, for instance, chapters $2,10,12,13,31,37,40,41,49$, and 50 .

8. Ibid., Vol. 1, 95.

9. Al-Dawah (October 1997).

10. Ibid.

11. J. Wiggins, In Praise of Religious Diversity (New York: Routledge, 1996), 39.

12. Qur'an (47:38), see Y. Ali. The Holy Qur'an: English Translation of the Meaning and Commentary (Saudi Arabia: King Fahd Printing Complex, 1989); M. Asad, The Message of the Qur'an Translated and Explained (Gibraltar: Dar Al Andalus, 1984), 783; A. Maududi, The Holy Qur'an: Translation and Brief Notes (Lahore: Islamic Publication, 1987); and T.B. Irving, The Qur'an (Beltsville, Md.: amana publications, 1985), 290. 
13. A. al-Qari, Al-Bahalil fi 'asr al-computer (Madinah, Saudi Arabia: Maktabat Ad-Dar, 1984), 22-23.

14. Ibid., 25-26.

15. See, for instance, Al-Dawah (September 1997): 38-39 and 50-51.

16. Ministry of Awqaf and Islamic Affairs, Al-Mawsu'ah al-fiqhiyyah, Vol. 32 (Kuwait, 1995), 195.

17. J. Esposito (Chief Ed.), The Oxford Encyclopedia of the Modern Islamic World, Vol. 2 (New York: Oxford University Press, 1995), 450.

18. J. Farganis, Readings in Social Theory (New York: McGraw-Hill, 1996), 420.

19. A. Kobeisy, "Women in Islam: Myths or Facts in American Universities."

20. See, for instance, The Message (March 1996): 37, and university documents on the project.

21. See pages $3-4$ of the agreement between the University and the Islamic community. 